\title{
The use [and refuse] of "progress" and "technology" as ideals of the Portuguese Estado Novo regime: a possible analysis of Lições de Salazar posters, 1938*
}

\author{
O uso [e a recusa] de "progresso" $e$ \\ "tecnologia" como ideais do regime \\ português do Estado Novo: uma possível \\ análise dos cartazes Lições de Salazar, 1938
}

Carlos Bártolo ${ }^{1}$

\begin{abstract}
From 1926 to 1974, Portugal went through a far-right dictatorship regime. At first, the main concern was to validate its arrival to power by presenting itself as the regime that was finally able to save the nation from previous circumstances. In order to achieve this, it was necessary to demonstrate how the government had the capacity of hauling the nation to the so-called developed countries level of progress. In 1938 seven posters entitled Lições de Salazar were printed and affixed at every school. Six represented different viewpoints of Salazar's economic miracle; the seventh represented the moral values over which education should be established, and hence the Nation. Through these posters analysis a contradictory message is perceived: the pressure to employ "progress" and "technology" as propaganda concepts, but also the reluctance in its use, since these notions were commonly associated to a "disruptive modernity", contrary to a conservative regime conscience.
\end{abstract}

Keywords: Portugal. Nationalism. Identity. Propaganda. Progress. Technology.

\section{Resumo}

Entre 1926 e 1974, Portugal foi um regime ditatorial de extrema-direita. Inicialmente, a principal preocupação foi validar a sua chegada ao poder apresentando-se como o regime finalmente capaz de salvar a nação das adversas circunstâncias anteriores. De forma a o conseguir, necessitava demonstrar como era capaz de elevar o país ao mesmo nível de progresso das nações ditas desenvolvidas. Em 1938 sete cartazes denominados Lições de Salazar foram impressos e afixados em todas as escolas. Seis representavam o milagre económico de Salazar; o sétimo representava os valores morais que deveriam reger a educação, e como tal a Nação. Através da análise destes cartazes uma mensagem contraditória entrevê-se: a necessidade de empregar "progresso" e "tecnologia" como conceitos de propaganda, mas também a relutância no seu uso, tendo em conta estas noções serem comummente associadas à disruptiva Modernidade, contrária à consciência conservadora do regime.

Palavras-chave: Portugal. Nacionalismo. Identidade. Propaganda. Progresso. Technologia. 


\section{Introduction}

In 1938, on the tenth anniversary commemoration of António de Oliveira Salazar (1889-1970) appointment as Minister of Finance, the Education Ministry printed an educational set of lithography posters entitled A Lição de Salazar [Salazar's Lesson]. They were affixed throughout the country's public classrooms, emphasizing the double meaning of "lição" [lesson] - as a simple didactic moment but also as a more profound ideological doctrine -, (fig.1) and thus stressing the school role in the new regime:

The school activity was expanded, its aim shouldn't be only to teach, but mainly to indoctrinate, politically indoctrinate in the noble sense of the word. More precisely: to disseminate knowledge that doesn't oppose, above all advocate the State moral bases; and to have constantly the concern that on the juvenile spirits should stay indelibly embedded the thought that the individual is worthless, if his effort isn't focused on the community service (RAMOS, 1937 , p. 6$)^{2}$.

Figure 1 - A boy's classroom in a state school, 1930-40's

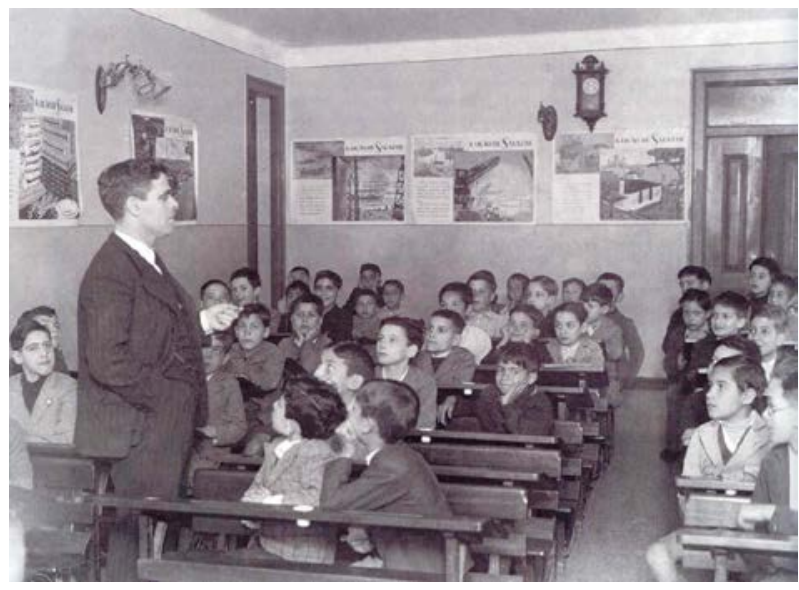

Fonte: (available on <http://restosdecoleccao.blogspot.pt/2012_06_01_ archive.html>)

At that time the regime was finally achieving a secured position, twelve years after the 1926 military coup détat. This coup was the outcome of an extended political crisis led by the failure to implement and stabilize a liberal and democratic system - monarchic and more recently republican -, experienced since almost one hundred years before.

After an unstable beginning, the regime found its pace under Salazar authority, a celibate conservative catholic economy professor invited in 1928 to straighten out the national debt as all-powerful Minister of Finance. Gradually, he secured prominent roles in the government until he arose to Prime Minister in 1932, incarnating a stoic persona that carried out the divine duty of fathering the country (RIVERO, 2010). With the 1933 Constitution ratification - establishing the power on a corporative regime entitled Estado Novo [New State] -, Salazar held his position in practice as a dictator, balancing out the different factions of the Portuguese far right. For the equilibrium of forces stretching from the poles of the ancien régime to the "pro-fascists", Salazar - himself a Conservative Catholic close to Integralism - created a single-party regime congregating, in the Establishment, reactionaries with modern-authoritarians while answering to different society sectors yearnings, all against the same unique enemy: the “social-liberal-democratic" system (ROSAS, 1989).

\section{Different propaganda for the same message}

Due to several factors these seven posters were conceived in a completely different way than other propaganda simultaneously produced by the regime. The most obvious reason was its target identification, children of every social stratum: from the poor rural worker's sons to the urban middle-class' ones. Accordingly the posters were conceived using illustrations with the same character than the mandatory school manuals. Their authors were Emmerico Nunes (1888-1965), Raquel Roque Cameiro (1889-1970), and Martins Barata (1899-1970), artists associated with a conservative and figurative genre of $\mathrm{art}^{3}$. The predominant use of realistic image over text - resumed to the title A Lição de Salazar and a sentence summarizing each case - was a result of the intention to fetch the broadest public possible: not only students but also the gullible analphabetic parents, unfortunately a majority ${ }^{4}$. These were simple lessons for simple people.

Another reason was the organism in charge of this edition: the Education Ministry, controlled by the party's most reactionary factions. As such its output was mainly traditional, not subscribing the most recent trends used

3 Followers of naturalistic and realistic movements they excelled in historical, landscape or genre painting - mainly the depiction of rustic, popular scenes and still lifes and at illustration - including for the official school manuals.

4 According to 1930 and 1940 population census, the Portuguese analphabetic population percentage was of 67,8 and 59,4\%, respectively (CARVALHO, 2011, p. 771). 
by the official propaganda department. During this first decade the Secretariado de Propaganda Nacional-SPN [National Propaganda Bureau], created in 1933 under the command of António Ferro (1895-1956) - a cosmopolitan writer associated with the Portuguese and European modernist and futurist milieu since his youth ${ }^{5}$ - was producing material of a much more innovative genre. The Portugal 1934 opulent photographic album ${ }^{6}$ (fig. 2) and the Portuguese pavilion ${ }^{7}$ information display at the 1937 Paris World Exhibition (fig. 3), conceived with the same goal, were perfect examples of this.

Figure 2 - Pages from Portugal 1934 photographic album

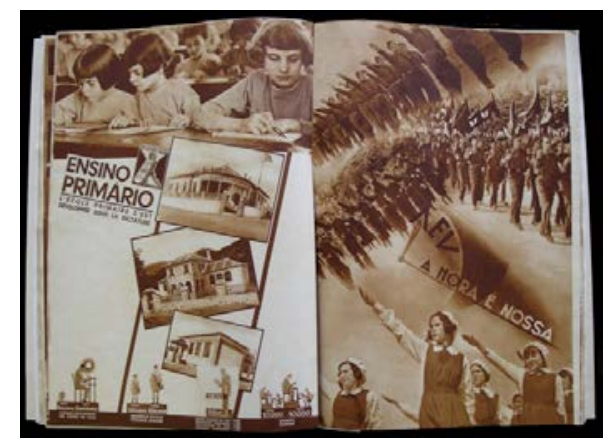

5 In 1915, with just 19 years old he was editor of Orpheu, the avant-garde magazine that laid the foundations of the Portuguese modernist movement with Fernando Pessoa, Mário de Sá-Carneiro and Almada Negreiros, among others. António Ferro wrote novels, poems and plays (some of which created some public outrage) while working as journalists for various newspapers and magazines. As an international reporter he interviewed personalities like d'Annunzio, Maurras, Pétain, Rivera, Mussolini and even Hitler but also Cocteau, Mistinguett or Poiret. Politically he began as a Republican Party sympathizer, evolving to the Sidonists (authoritarian modern) and the Conservative Republicans, while gradually admiring the contemporary authoritarian regimes, especially Mussolini's. In 1932 when interviewing Salazar they discussed the political role of the culture; months later his political career began when invited to SPN.

6 Recently presented in Martin Parr and Gerry Badger third volume of The Photobook: A history as a "book that approaches the exuberant quality of the Russian [soviet propaganda] books" (PARR; BADGER, 2014, p. 16) designed by Alexander Rodchenko or El Lissitsky.

7 The pavilion was designed by architect Francisco Keil do Amaral (1910-1975), with interiors created by some artists of what would become known as the "SPN artists-decorators" team. This accommodating group would integrate, according to the period or commission, Bernardo Marques (1898-1962), Carlos Botelho (1899-1982), Eduardo Anahory (1917-1985), Emmérico Nunes, Estrela Faria (1910-1976), José Rocha (1907-1982), Manuel Lapa (1914-1979), Maria Keil (1914-2012), Fred Kradolfer (1903-1968), the Novais brothers (Mário 1899-1967, Horácio 1910-1988), Paulo Ferreira (1911-1999), and Tom (1906-1990).
Figure 3 - Interiors of Paris 1937 Portuguese pavillion. Exposição Internacional de Paris, 1937.

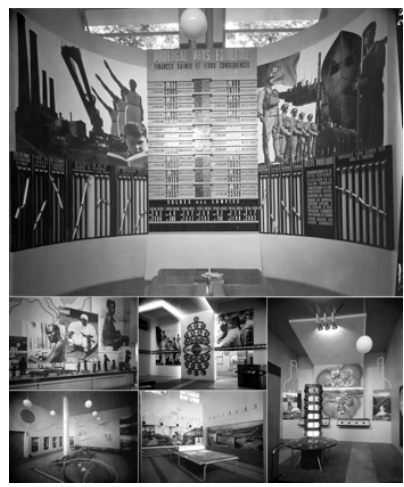

Fonte: (PORTUGAL. SPN, 1934, n.p.); Photo Mário Novais [1937]. Col. Estúdio Mário Novais. FCG-BA

On them, with the help of his modernist "old comrades", Ferro presented the same discourse, laudatory of the regime, supported on statistical data mapped on: photography, forms, colours, simple graphics and modern typography, assembled, in the pavilion case, over geometric three-dimensional compositions that enveloped the spaces. In these works were perceivable influences from experiments of recent avant-garde graphic and exhibition design like: El Lissitzky's 1928 Soviet pavilion, and catalogue, at the Pressa exhibition in Cologne; or Adalberto Libera and Mario de Rizi's 1932 Mostra della Rivoluzione Fascista in Rome ${ }^{8}$. Naturally the public lured by the SPN was diverse: this was propaganda conceived to Portuguese - and foreign - literate classes, not the common analphabetic peasant; to people used to the cosmopolitan terraces of Lisbon, Paris or New York, and not to someone that didn't knew what was outside his village limits, and where the modest teacher's classroom was considered the most enlightened place on earth. Nevertheless, these posters composition should be alluded on the use of coherent and functional graphic communication laws that efficiently contributed to getting the message deliver.

\section{The lessons}

Six of these posters promulgated the "miracle" occurred during those ten years of Salazar guardianship (fig. 4). Each one has the same composition: two ima-

8 Other artists collaborated in this exhibition like Marcello Nizzoli, Giuseppe Terragni, Mario Sironi, Achille Funi and many others 
ges, one smaller (the "before") on the upper left corner slightly superimposed by a bigger and more colourful one (the "after") on the opposing corner. At the residual space the title, on the upper right corner - printed in black with Salazar's initial S bigger than the other letters thus highlighting the dictator's name - and a short emphatic caption on the remaining quadrant. The predominant elements are thus shown in a diagonal line, recurring to different layers, dimensions and tonal scales, stressing the dynamic action that wants to be revealed: the transfiguration from an ulterior moment to a subsequent present. Cascading from the left upper corner to the bottom right, the oblique composition was emphasizing the solidness of what had been achieved: the present.

Figure 4 - A Lição de Salazar evolution posters by: Raquel Gameiro 1st, 5th; Martins Barata 2nd, 3rd, 6th; Emmérico Nunes 4th

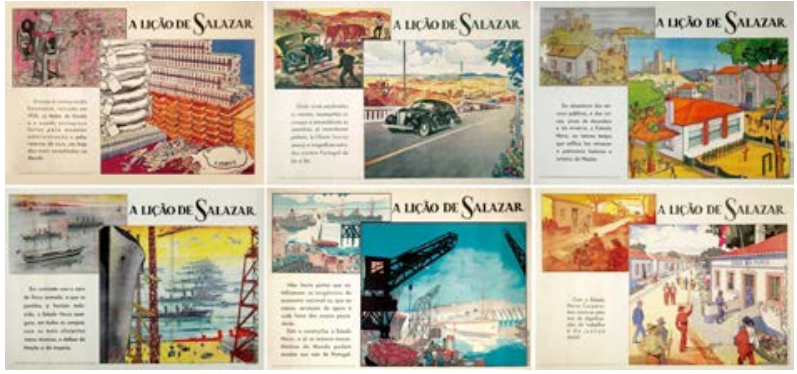

Fonte: (PORTUGAL. MEN et. al., 1936, 1-6)

Through these operative means, that underlined the change from a recent "decadent" past to a fulfilled present, six topics were announced: the achieved financial stability; the improvement on communications and agriculture; the cultural heritage recovery and public infrastructures construction; the armed forces growth; the commercial ports development supporting the economy; and the work and social conditions enhancement achieved through the corporative system.

Modern technology outcomes were discerned in almost all of these posters: modern cars roaring over perfect country roads contoured with new telecommunications lines; similar cars and lines crossing the village's centre equipped with revamped public buildings and modern schools where uniformed children played; a bustling shipyard and endless formations of aeroplanes, submarines and warships traversing a bay; lines of busy cranes unloading cargo from modern freighters moored near enormous passenger liners; everything contrasting with corresponding gloomy "before" scenes.
All this information, even if slightly enhanced, was the result of a State endeavour to recover and haul the nation to the same level of progress reached by the so-called developed countries (something deficiently tried to achieve since the establishment of the liberal regime in the 19th c.). Through a determined policy of infrastructure development, Política de Obras Públicas [Public Works Policy], carried by the minister Duarte Pacheco (1900-1943), roads, airports, and ports were developed; hospitals, schools and other public equipment built; hydroelectric plants raised and modern communication networks spread. This effort was permanently announced, as the government main concern was to validate its recent arrival to power by presenting itself as the regime that finally was able to save the nation from previous harmful socio-politic circumstances (decades of liberal and democratic ephemeral "chaotic" governments) that had dramatically wreaked the feeble Portuguese economy.

\section{The trilogy poster}

Notwithstanding, for this essay, it's the remaining poster - different from all others graphically and in content- that turns up more revealing of the regime intentions.

The double "before/after" illustrations scheme was replaced by one single image. The title is still in the upper right corner, but presented more colourfully, in black with L and S red initials over a yellow scroll; on the opposing quadrant, a classic tablet with the short legend Deus, Pátria e Família: A Trilogia da Educação Nacional [God, Fatherland and Family: the National Indoctrination Trilogy], in the same colour range with highlighted $\mathrm{D}, \mathrm{P}$ and $\mathrm{F}$ initials. The oblique dynamic composition mentioned before vanished in a poster that didn't want to express an evolution or comparison, but to affirm a unique, solid and immutable stance.

Graphically this was achieved extending the image all through the surface reducing the texts to floating secondary elements, hence the need of scroll and tablet. Even the image's tonal density was balanced. The decision to distinguish this poster from others stresses its importance as the one where, more than simply present facts, fundamental principles to the regime were proclaimed. 
Figure 5 - A Lição de Salazar trilogy poster by Martins Barata

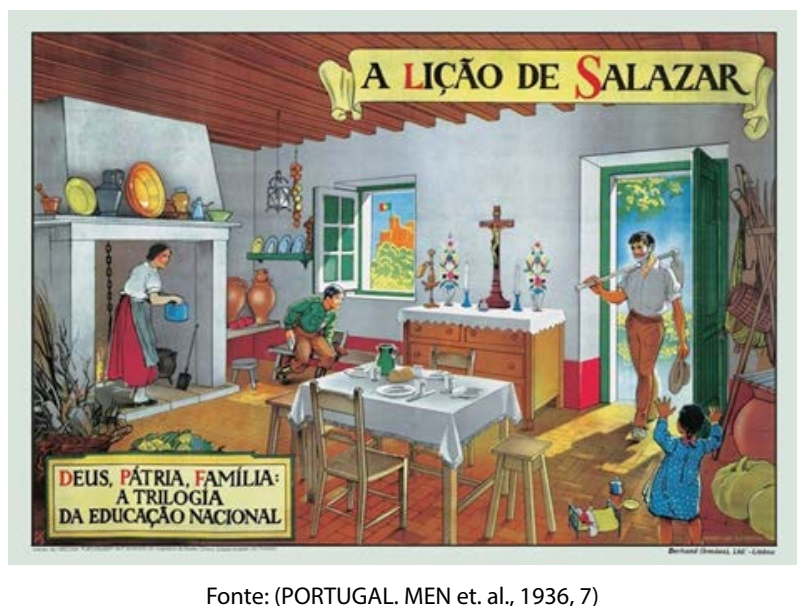

This seventh poster depicted just one scene happening in a domestic interior (fig. 5). Through the open door and window is possible to realize that it is a modest one-storey house with direct access from outside. The room is flood with warm and yellowish sunlight, creating a joyful ambiance for the effusive moment where a father arrives from work and is cheerfully welcomed by the family.

In this room the desired moral trinity God, Fatherland and Family -fundamental dogmas of Estado Novo (abiding Catholicism, obedient nationalism, and traditional family morals) -, is presented in a scene that assembles all on a singular picture. Salazar had previously formulated this "trinity": at a conference in 1912, he had already said "only one entity apprehend my main thought: the Christian-democrat perfectly consolidated in the family, fatherland and religious society should be the useful entity during this historical moment when each individual discourse try to be a social inutility". (SALAZAR, 1997, p. 178) and on The National Revolution Great Certainties discourse of 1936 he proclaimed: "we don't discuss God and virtue; we don't discuss Fatherland and its History; we don't discuss authority and its prominence; we don't discuss family and its moral; we don't discuss work exaltation and its duty" (SALAZAR, 1937, p. 130).

The caption proclaimed this group of interconnected values according to their hierarchy, from the universal ("God" as creator) to the particular ("Family" as primordial social unity): "[family was the] irreducible social cell, original nucleus of the village, the county and, therefore, the Nation: it is, by nature, the primary organic element of the constitutional state" (SALAZAR, 1935, p. 85). The "Individual" was excluded from this representation, as it wasn't, per se, social. Charles Barrès, one of the "nationalism" and "fascism" fathers, said "But don't you know that the individual is nothing, and society everything?” (BARRÈS, 1922 [1897], p. 261); and years later Salazar declared "The 19th c. liberal politics made "citizen" an individual dismembered from family, class, profession, cultural environment or economic aggregation, and gave him, facultatively, the right to intervene on the State constitution" (SALAZAR, 1935, p. 85).

In the poster "God" is perceived in this devotional ensemble over the chest of drawers, and "Fatherland" on the castle's waving flag seen through the window and on the son's Mocidade Portuguesa official uniform ${ }^{9}$. Nevertheless, of these three values, the focus is on "Family", thus understood as the system nucleus, simultaneously consequence and origin of them all,

There [in the family], the man is born; there, generations are educated; there, the small world of affections is formed, without which he can hardly live. When the family falls down, the house falls down, the home falls down, the kinship bonds fall down, and the men remain isolated before the State, strange, without support, morally stripped of half of themselves; a name is lost, a number is acquired - the social life promptly heads in a different way (SALAZAR, 1937, p. 134).

By choosing "Family" as fulcrum value, Salazar was also portraying the dictatorship citizen primeval duty: uncritical obedience. Respect and obedience to fathers - more precisely "the" father, the family chief signified obedience that all should maintain to their superiors: "God" on the divine domain; and on the earthly world - the "Fatherland" - its supreme leader, the dictator: "[obedience was the] high gift of providence, as without it nothing could be possible on social life, or human civilization [...]. In family, school, church, workshop, guild, army quarter or State, authority never exists for itself but for others" (SALAZAR, 1937, p. 122).

It's also interesting to perceive how "Family" concept is presented in this picture in its minimal but ideal configuration: a couple and their pair of one son and one daughter. In this representation all performed their traditionally ascribed roles: a working father, in charge of the family means of support, coming from outside; a homely

9 Mocidade Portuguesa was the compulsory Portuguese youth organization created by Estado Novo in 1936, and originally inspired upon the model of the Italian Fascist Opera Nazionale Balilla and the German National-Socialist Hitlerjugend 
mother responsible for nourishment, the care of house and offspring; a young daughter, innocently playing with dolls, thus already learning her attributed place in society; and an uniformed boy studying to obediently serve the Country, and God, as respectfully as he saluted his father, in reality the only one that could break the perpetual primitive rural life cycle through work and studies, holding the only book visible in the room, testimony of the existence of a single unquestionable truth in the entire nation. Interestingly the men stand next to the sunny outside openings and the women are sheltered in the interior but in spite of the outside-inside locations, they are all united on the most sacrum place, inside their own home ${ }^{10}$. "House", "nest", "home" were here understood as a primal space for the physical and spiritual values safekeeping, refuge from malevolent external influences. As a result "Home", as symbol, stood for "Family" and consequently for "Fatherland".

Therefore the importance of this innocent representation: not any house, but the Portuguese Family Home as an abstract entity; not a realistic model to be copied, but the representation of ideals that all should spiritually attain.

In this manner these "family" and "home" representations were the sum of attributes understood as this pursued abstract concept signifiers. They were intended to represent costumes, details and characteristics easily and broadly regarded as vernacular Portuguese, but that shouldn't be attributed specifically to a particular region, thus creating a mingled reinvented tradition (HOBSBAWM, 2003 [1983]), a fake and generic national symbolic repertoire endlessly repeated without acrimonious regional disputes. "Nation" and "People" perceived as a single entity.

\section{The Portuguese Home}

Returning to this paper aim - understand how Estado Novo understood the role of progress and technology on Portugal - it should be analysed how technology was addressed in the trilogy poster.

The room, while small in dimensions, accommo-

10 The etymological origins of lar, família, pátria e nação [home, family, fatherland, and nation] can all be intertwined on wide ranging definitions that underline the 'group' or 'belonging' meaning. dates a diverse group of functions:

living - the boy studying in a corner and the girl playing on the floor;

eating - the dinner table ready in the middle of the room: ${ }^{\circ}$ cooking - with the mother preparing a meal at the chimney surrounded by firewood, ingredients and kitchen utensils; storage of personal items or of farming activity - the chest of drawers and tools and stored goods, pumpkins and other goods in baskets and earthen vessels; and of devotion - on top of the chest a crucifix flanked by flower vases, candlesticks, and a brass oil lamp.

The only house function spaces missing were the sleeping and hygiene ones, both too sinful, according to the Christian morality, to be represented. Apart from the devotional ensemble - naturally the most ornate and important room pieces - the other objects obeyed mainly to strict constructive and functional simplicity, with discreet decorative details in some furniture and on some table set items. The general spirit was of modesty and poverty, not miserabilist but ascetic; a family proud of its barely but honest possessions. The home was in pristine and ordered condition: ironed cloths, shinning metals, whitewashed walls... everything in its place. While there isn't any display of wealth and luxury on the objects, the abundance of food denoted that there was no famine, and the sustenance and well-being was, at reasonable modest limits, attainable. Overall the entire scene emanated calm, joy, happiness and bonhomie: "[...] the reasonable house, house of the poorest, salubrious house, independent, arranged like a nest - home of the workers family, modest home, restrained, Portuguese". (SALAZAR, 1935, p. 323)

If the first posters displayed elements of civilizational and technological progress, the last one presented none. Instead of fast automobiles, zigzagged roads, rows of telecommunication poles, mighty cranes, liners, airplanes, warships, submarines, etc., there was just a simple and humble rural home, lost on Salazar's locus amoenus. No sign of electric light, a house being lighted with candles, lanterns and oil lamps. Also no signs of plumbing, with earthenware and tinfoil water jugs visible around the chimney. No signs of modernity at all, as the mother continued cooking with caldrons and iron cast pots in the chimney. None of the domestic appliances long time developed are in sight: a radio, a telephone, a refrigerator, a gas or electric stove (in fact not even a charcoal, kerosene or wood-burning stove), benefits that the modern techno- 
logic progress had already trivialised on many Portuguese urban houses. In the 1930's the country electrification was one of the public infrastructures being developed ${ }^{11}$, with the State assuming that task, and since the 1920's the gas and electricity companies were vigorously promoting the use of every kind of electric and gas appliances and educating on its use (fig. 6).

Figure 6. CRGE 1937 electricity campaign posters by Guy(?)

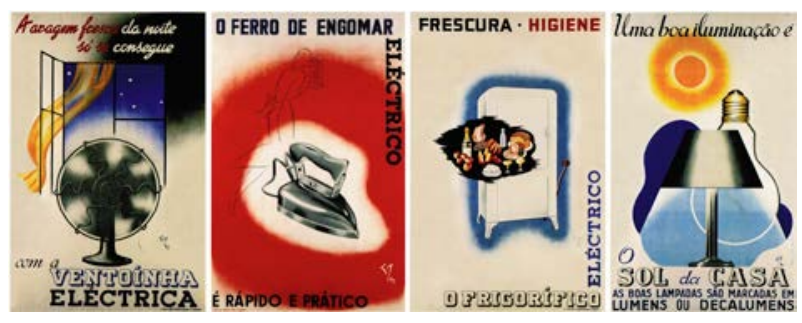

Fonte: (FARIA; FREITAS, 2000, p.41, 43, 45, 35)

In reality all objects of this home could be found in a mid 19th c. house, if not earlier, and hadn't been, since then, subject to many alterations: formal, functional or of production.

The sparse existent furniture - a chest of drawers, a table, two chairs, two stools, a long bench and the low three-legged stick tabouret - correspond to models from the national vernacular furniture. With forms that had unhurriedly evolved on the popular production (bench, stools, tabouret and table) even if absorbing, and adapting, forms and details from more up-scale models (chairs, and chest of drawers), most of them were the result of local craftspersons or small cabinetmaking workshops, where the use of some technology could be admitted ${ }^{12}$.

On the other hand articles associated with the farming activity were also result of these productive systems: containers made by basket weavers in willow or oak, wooden kegs and agricultural tools made by local coopers and artisans, when not by the farmer himself.

The other domestic objects, in its majority, indicate similar origins, as being produced at small artisanal

11 The distribution of piped gas in Lisbon and its outskirts for public lightning and domestic use had begun in the mid 19th c.; and electricity production began in 1889, quickly supplanting the gas as light energy, while the gas network persisted in Lisbon for domestic use (cooking and water heating).

12 Nevertheless, this use of machinery didn't alter the production processes and technics and only were introduced so some of the operations could be less painful or time-consuming. workshops. The ceramic ones - a big storage urn, bowls of varied sizes, glazed and unglazed water vases and jugs - were all formed on potter's wheels in small workshops throughout the country and acquired in local fairs and markets, regionally varying on formal and decorative details. Also the metallic ones - tinfoil lanterns, olive oil bottles and water jugs, fireplace dogs and crane, iron shovels and brass mortar or oil lamps - come from the local blacksmiths, tinkers, and forges.

In reality all through this home only some objects looked like they were mass-produced: the cutlery; the casted iron pots and hoe's blade; the enamelled or earthenware white plates; the also glazed and painted earthenware candlesticks and flower vase; the drinking glasses and small devotional oil lamp in pressed glass; the printed book and the printed calico fabric of the daughter's dress. Nevertheless all done through methods developed during the initial Industrial Revolution, at the second half of the 18th c. or during the beginning of the subsequent century.

Even the family clothes shapes, exception made to the son's Mocidade uniform, belong to an "uchronic" time, making it difficult to date the scene.

\section{Technology and progress at a conservative country}

Salazar, or the regime, didn't intend to force Portuguese people, urban or rural, to return to a pre-Industrial Revolution crude way of life, done according to Luddites principles. In fact it shouldn't be forgotten that a great part of the population was still living in similar conditions, specifically the lower classes and the ones residing outside the main urban centres. Nevertheless this was the model chosen to represent the social and moral values, the depiction of the founding ideological principles, and not one that derive from the existent and flourishing urban contemporary life.

The first posters revealed the demand to modernize the national infrastructures, subsequently improving the population well being, but the regime didn't intend to place the progress and comfort desire, referral of the technological contemporaneity, at the top of Nation's principles. Not even the Public Works Policy - fundamental to the regime propaganda and acceptance - could be motive enough to alter the corporative system backbone, its traditional values. In 1952 Christine Garnier adulatory 
interview/book ${ }^{13}$, a dialogue between the dictator and the journalist elucidate, once more, his viewpoint:

- So, Madame, what impressions do you take from Portugal?

- One of calm, Mister President, probably of extreme calm. I would say numbness.

- That calm that impresses you is intentional. - he said - We apply ourselves to protect it from everything that could hurt it, but that doesn't refrain the Portuguese people, that isn't unconscious or uninterested, to be attentive to the world events. I frankly think that the permanent frenzy and exultation in which some regimes maintain their people is a bad and insane thing. [...] I consider this calm one of the present time Portuguese people characteristics. [...] I eagerly wish that our small piece of land preserve this precious gift, common to so many nations in a recent past: the sweetness of tranquil living. Nobody can deny that we, until now, managed to achieve that goal.

The sweetness of a tranquil living.... I melancholy repeated these words. I think on the flowers, on the people that peacefully wander through Lisbon. I remember the nights when quiet men sit on the belvederes contemplating the city lights, while fados roam through the streets. In Portugal, the people still have time to feel, and guard the pleasure of dreaming. Anyway, I think again of Salazar in his vineyards, quietly chatting with peasants and stonemasons, unhurried, like he owns eternity. In which other country can we find this spirit today? While Salazar vehemently evoke the Portuguese serenity, it looks like we're hearing a healthy man mourning his sick companions, or a wealthy man bragging his home to the unfortunate ones. And this triggers in me some sadness.

- The experience teach us - he continues - that an intense economical activity, the best technological progress, the most profound social reforms leave undamaged the qualities of our people if, by all careful means, we manage to keep their hearts pure and their thoughts sane. That's why we keep the spirit above everything.

The spirit? That's the keyword, the word that better define Salazar politics. For him, whatever the realm, everything is a projection of the spirit. He believes that the spirit mould and transform men more profoundly than dominant forces. Didn't he said once that peace is, overall, a creation of the spirit?

- According to this condition - said Salazar we pursue, as fast as we can, with the national reconstruction work. You shouldn't forget that

13 The original Portuguese version entitled Férias com Salazar [Vacations with Salazar], was published in various idioms during the subsequent years. one of our agenda items was to bring us up to date since, due to different causes, and in many domains, we let ourselves regretfully to fall behind. (GARNIER, 1952, p. 219-222)

However necessary the demand to "bring us up to date", this created problems with nuclear nationalistic ideals: how could the nation pursue its attempt to even out other progressive nations while simultaneously preserving its necessary moral sovereignty free of "malevolent" international influences? Especially when this progress was commonly associated to the "Liberal" or "Bolshevik disruptive modernity", contrary to the continuousness need of a conservative regime, even one making an effort to built a "new state".

In this inconsistent set of "six plus one" posters, it's perceivable the incongruous Estado Novo attitude towards technology, progress or modernity. Lost in a dilemma where the unstoppable modern condition collided with perennial values, and even acknowledging the propaganda demand for facts to self-announce the nation growth, the regime opted to divide the world in two realms: a physical and a spiritual one, vigorously promoting the latter merits, and subordinating to them the former ones.

\section{A serene nation on an unrested world}

Regarded in the broadest sense as fascist, Estado Novo attempted to differentiate itself from other contemporary systems as an "original” non-belligerent hybrid regime that, while trying to modernize a underdeveloped country, simultaneously kept it lost in this kind of "gone-by glorified, bucolic and pious dream". This position was clear in the national "discourses" to the 1937 Paris and 1939 New York expositions, both events about contemporaneity and future ${ }^{14}$. In Paris, Portugal exhibited the "modern life art and technique of ruling a country" displaying the success of Salazar's regime work through the results avant-gardist mapping, as previously referred. But in spite of that the itinerary climaxed on a contrasting room entirely dedicated to an extensive ethnographic collection of popular artefacts while, on the pavilion terrace,

14 The Paris 1937 event was entitled Exposition Internationale des Arts et Techniques dans la Vie Moderne [International Exposition dedicated to Art and Technology in Modern Life]; and the theme of the 1939-40 New York World's Fair was 'Dawn of a New Day/The World of Tomorrow'. 
folkloric dance and music played in parties that mimicked traditional summer festivities (fig. 7).

Figure 7. Paris 1937 pavilion's popular arts room and three of the decorator-artists dancing with guests dressed in folkloric costumes at the 28th July inaugural ball. Exposição Internacional de Paris, 1937.

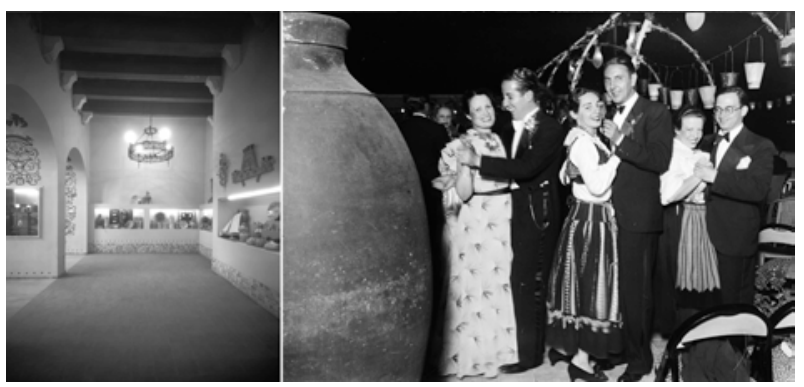

Fonte: Photo Mário Novais [1937]. Col. Estúdio Mário Novais. FCG-BA

In the New York exposition, renown for several utopic futuristic presentations, after a lengthy presentation of the Portuguese discoveries role and the country economic endeavour results, Portugal presented, on bucolic gardens, its own "world of tomorrow", an allegoric ensemble of captions, photographs, bas-reliefs, and a sculpture placed on an elevated terrace. The central piece was composed by: a lower bas-relief representing labour; an higher one the family; and on top a sculptured stylized depiction of a white small country village surrounding a church, all this set in front of a photographic collage panel of natural and industrial landscapes with white sculpted doves scattered (fig. 8).

Figure 8. "The gardens with a symbolical group of the Portuguese World of Tomorrow" drawing, Carlos Botelho and José Rocha (project), Canto da Maia (sculptor). O mundo de amanhã, projecto de Carlos Botelho e José Rocha, escultura de Canto da Maia.

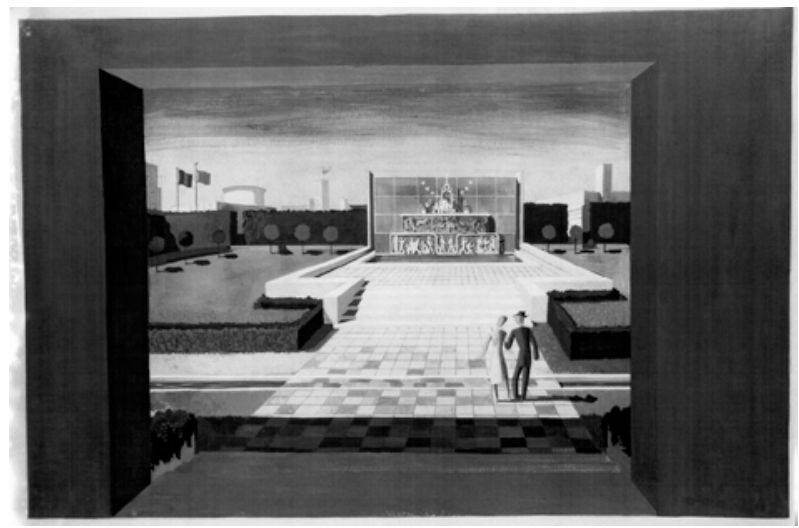

Fonte: Photo Mário Novais [1939]. Col. Estúdio Mário Novais. FCG-BA

The captions emphasized the ensemble ideas quoting, one more time, Salazar: "civilization includes progress but progress alone does not include civilization.\$ We propose to build up a social and corporative state which shall correspond to the natural structure of society". (COSTA, 1939)

Once again the traditional over the technology, the spiritual over the physical world.

This aversion to technology would delay the necessary and fruitful interdependence between design and a, once again, disregarded industrialization, but in spite of that, the discussion in good taste, culture and identity matters - promoted by propaganda efforts of the $S P N$ - and its profuse graphic and exhibition production, while seemingly distant from the modernist canon, would support the appearance of the discipline conscience and of a generation of artists that would be the "grandfathers" of the Portuguese Design, "born" a few decades latter.

\section{References}

BARRÈS, Maurice. Les Déracinés: Le Roman de L'Énergie Nationale. 8. ed. Paris: Libraire Plon, 1922.

CARVALHO, Rómulo de. História do ensino em Portugal. 5. ed. Lisboa: Fundação Calouste Gulbenkian, 2011.

COSTA, Marques da. (Org.). Portugal in the New York World's Fair 1939: the Official Book of the Portuguese Representation. Lisbon: SPN, 1939.

FARIA, Fernando; FREITAS, Maria Helena. Electricidade e modernidade: cartazes. Lisboa: Museu da Electricidade EDP, 2000.

GARNIER, Christine. Férias com Salazar. Lisboa: Parceria António Maria Pereira, 1952.

HOBSBAWM, Eric. Introduction: inventing traditions. In: HOBSBAWM, Eric; RANGER, Terence (Ed.). The invention of tradition. 11. ed. Cambridge: Cambridge University Press. 2003. p. 1-14.

PARR, Martin; BADGER, Gerry. The photobook: a history. Londos: Phaidon Press, 2014.

PORTUGAL. MEN [Ministério da Educação Nacional]; BARATA, Martins; GAMEIRO, Raquel; NUNES, Emmerico. A Lição de Salazar [set of seven posters]. Lisboa: MEN/ Bertrand, 1936.

PORTUGAL. SPN [Secretariado de Propaganda Nacional]. Portugal 1934. Lisboa: SPN, 1934.

RAMOS, Gustavo Cordeiro. Os fundamentos éticos da escola no Estado Novo. Lisboa: [s.n.], 1937. 
RIVERO, Ángel. Salazar and Charismatic Leadership [Online]. London: The London School of Economics and Political Science, 2010. Available on: <http://www.lse. ac.uk/researchAndExpertise/units/ASEN/Conference/ PastConferences/2010/conferencepapers2010/Angel_Rivero.pdf>. Access on: 20 Mar. 2012.

ROSAS, Fernando. A crise do Liberalismo e as origens do «Autoritarismo Moderno» e do Estado Novo em Portugal. Penélope, Fazer e Desfazer a História [Online]. Lisboa: Cooperativa Penélope; Quetzal Editores. p. 98-114, 2 Feb. 1989. Available on: <http://www.penelope.ics.ul.pt/ indices/penelope_02/02_08_FRosas.pdf $>$. Access on: 26 Mar. 2012.
SALAZAR, António Oliveira. Conferência na reabertura do CADC (1912). In: CRUZ, Manuel Braga da (Ed.). Inéditos e Dispersos I (1908-1928). Venda Nova: Bertrand, 1997. p. 175-197.

SALAZAR, António Oliveira. Discursos, 1928-1934. Coimbra: Coimbra, 1935

SALAZAR, António Oliveira. Discursos e notas políticas, 1935-1937. Coimbra: Coimbra, 1937 